\title{
Važnost vježbanja kod oboljelih od dijabetesa
}

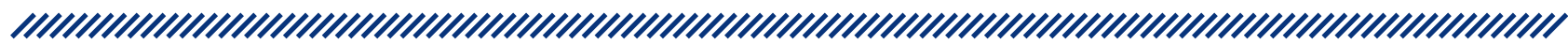

1 Petra Šulevski

1 Ivna Kocijan

2 Zdravstveno veleučilište, Zagreb

\section{Sažetak}

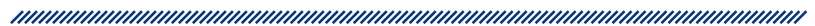

Sve je veći broj oboljelih osoba od dijabetesa, kako u svijetu tako i u Hrvatskoj. Procjene govore o ukupnoj brojci od 415 milijuna oboljelih. Broj oboljelih, a posebice onih s dijagnozom dijabetesa tipa 2 , upućuje na neuredan način života, odnosno loše prehrambene navike, sedentaran način života i stres. Liječenje dijabetesa provodi se pravilnom prehranom, redovitom tjelesnom aktivnošću i medikamentnom terapijom, a sve u cilju regulacije glikemije. Tjelesna aktivnost sastavni je dio liječenja dijabetesa jer se njezinim provođenjem održava odgovarajuća razina glikemije, poboljšava lipidni status te povećava osjetljivost stanica na inzulin. Ujedno se vježbanjem smanjuje potreba za inzulinom jer mišići svojom kontrakcijom pojačano troše glukozu.

Dozvoljene su sve vrste tjelesne aktivnosti, ponekad uz određena individualna ograničenja, a najviše koristi polučuje ako se vježbanje provodi redovito i uz umjereni intenzitet, ali uz određeni oprez, posebice ako su prisutne komplikacije bolesti. Posebnu pažnju treba posvetiti riziku od hipoglikemije, jer se prilikom tjelovježbe smanjuje razina glukoze. Prije provođenja tjelesne aktivnosti potrebno je provjeriti razinu glukoze te tomu prilagoditi tjelesnu aktivnost ili je odgoditi u slučaju previsoke ili preniske razine.
Istraživanja su pokazala da aerobne i anaerobne aktivnosti utječu na regulaciju glukoze. Prije svega, preporučuju se vježbe fleksibilnosti (iako nemaju izravan utjecaj na smanjenje glukoze) te vježbe balansa, koje smanjuju mogućnost padova. Preporučuje se $150 \mathrm{mi}-$ nuta tjedno umjerene do snažne aktivnosti.Primjerice, vježbe se mogu provoditi umjerenim intenzitetom uz 15 ponavljanja ili jakim intenzitetom uz šest do osam ponavljanja.

Možemo zaključiti da je redovita tjelovježba nužna za očuvanje zdravlja i kvalitete života oboljelih od dijabetesa.

Ključne riječi: dijabetes tip 1 , dijabetes tip 2, tjelovježba, regulacija glukoze

Datum primitka: 10.07.2018.

Datum prihvaćanja: 15.10.2018.

DOI: $10.24141 / 1 / 5 / 1 / 11$

Adresa za dopisivanje:

Ivna Kocijan

Zdravstveno veleučilište, Mlinarska 38, Zagreb

tel.: +38515495726

e-pošta: ivna.kocijan@zvu.hr 


\section{Uvod}

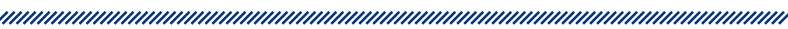

Šećerna bolest (lat. diabetes mellitus) jest bolest koja je u porastu diljem svijeta, a u razvijenim zemljama gotovo je dosegnula epidemijske razmjere. S obzirom na razmjere bolesti, potrebno je podignuti razinu znanja i svijesti o samoj bolesti te je prepoznati na vrijeme i poduzeti adekvatno liječenje.

Najčešći je oblik bolesti dijabetes tip 2, koji se uspješno regulira redovitom tjelovježbom, pravilnom prehranom te peroralnim antidijabeticima ili inzulinom. Dijabetes tip 1 autoimuna je bolest koja se također uz inzulin, tjelesnu aktivnost i prehranu može držati pod kontrolom.

Cilj je ovog rada prikazati važnost vježbanja u kontroli bolesti, kao i različite vrste vježbi, te ograničenja koja je potrebno uzeti u obzir prilikom provođenja tjelesne aktivnosti. lako je dijabetes vrlo ozbiljna bolest koja često nosi mnogo komplikacija, tjelovježba, odnosno terapijska vježba je jedan od važnih faktora u liječenju bolesti, ali je pritom potrebno posjedovati znanja kako bi se sigurno provodila u svakodnevnom životu oboljelih. Prilagođena tjelesna aktivnost doprinosi smanjenju glukoze u krvi i cjelokupnom zdravlju.

\section{Teorijski pristup}

\subsection{Pojmovno određenje}

Prema Svjetskoj zdravstvenoj organizaciji (engl. World Health Organizaiton, WHO), dijabetes je skupina metaboličkih poremećaja u kojem je povišena razina glukoze u krvi koja nastaje kao posljedica relativnog ili apsolutnog manjka lučenja inzulina ili smanjene inzulinske osjetljivosti. ${ }^{1}$ Drugim riječima, šećerna bolest jest metabolička bolest karakterizirana kroničnom hiperglikemijom koja nastaje kada gušterača prestane djelomično ili potpuno proizvoditi inzulin ili ako je u organizmu smanjeno djelovanje inzulina. Hiperglikemija uzrokuje daljnje komplikacije u vidu oštećenja ostalih organskih sustava ponajprije oštećenjem krvnih žila te je uzrok sljepoće i invaliditeta. Promjene se najčešće uočavaju na malim krvnim žilama (arteriolama) očne pozadine, bubrega i koronarnim arterijama. Stoga se šećerna bolest smatra ozbiljnom kroničnom bolešću i predstavlja faktor visokog rizika za pojavu progresivne bolesti poremećaja cirkulacije na vitalnim organima kao što su srce, bubrezi i mozak. ${ }^{2}$

Prema Međunarodnoj dijabetičkoj federaciji (engl. International Diabetes Federation, IDF), u svijetu je 415 milijuna osoba oboljelih od dijabetesa, a procjenjuje da će do 2040. godine biti 642 milijuna oboljelih. Gotovo polovica (46,5\%) odraslih osoba koje boluju od šećerne bolesti još uvijek nema postavljenu dijagnozu. Liječenje šećerne bolesti i njezinih komplikacija čini 12 \% svjetskih troškova za zdravstvo, oko 673 milijarde dolara. ${ }^{3}$

\section{Tjelesna aktivnost i dijabetes}

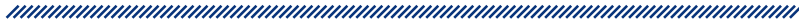

Tjelesna je aktivnost važan i sastavni dio svakodnevnog života pojedinca te podrazumijeva aktivnosti kao što su sport i rekreacija, ali i svakodnevno hodanje, obavljanje kućanskih poslova i mnoge druge. Razina tjelesne aktivnosti uvelike se razlikuje od osobe do osobe pa su tako neki više, a neki manje aktivni. Na primjer, neki voze bicikl umjesto automobila ili hodaju do posla, neki upotrebljavaju stepenice umjesto dizala, a neki se bave i strukturiranom tjelovježbom. ${ }^{1}$ Dakle, postoje velike individualne razlike i navike u svakodnevnom životu ljudi.

Tjelesna aktivnost označava sve aktivnosti koje uključuju povećanje energije, dok je tjelovježba planirana, strukturirana i usmjerena određenom cilju. ${ }^{1}$ Pod pojmom tjelovježbe smatra se redovito provođenje tjelesne aktivnosti prema određenom planu i postavljenom cilju koji se njome želi postići te je determinirana frekvencijom, intenzitetom i trajanjem. ${ }^{1}$

Kineziterapija (drugi nazivi: terapijska vježba, medicinska gimnastika, terapijska gimnastika i drugo) se bavi proučavanjem i primjenom pokreta pojedinih dijelova tijela ili cijelog tijela kao vježbe radi liječenja oboljelih i ozlijeđenih osoba. Služi za liječenje i profilaksu ili se kombinira s drugim oblicima fizikalne terapije. ${ }^{4}$

Od posljedica neaktivnosti svake godine umire 3,2 milijuna ljudi, prema procjenama Svjetske zdravstvene organizacije. ${ }^{5} \mathrm{Niz}$ je bolesti povezan s neaktivnošću, kao što su dijabetes tip 2, kardiovaskularne bolesti, preti- 
lost, hipertenzija i druge. Tjelesna neaktivnost smatra se četvrtim uzrokom smrtnosti te oboljeli od dijabetesa žive pet do deset godina kraće u odnosu na osobe koje nemaju dijabetes. ${ }^{6}$ Tjelovježba i drugi oblici tjelesne aktivnosti vrlo su važan faktor u prevenciji mnogih bolesti i održavanju zdravlja. Važno je da se tjelovježba provodi redovito da bi imala željen učinak u održavanju zdravlja. Cilj je tjelovježbe očuvanje mišićno-koštanog sustava, ponajprije povećanjem mišićne snage i opsega pokreta, te kardiovaskularnog sustava.

Tjelesna je aktivnost nužna za održavanje odgovarajuće razine glukoze u krvi i održavanje cjelokupnog zdravlja osoba s dijabetesom i predijabetesom. Tjelesna aktivnost ima mnoge dobrobiti ako se provodi redovito i umjerenog je intenziteta. Klinička ispitivanja pokazuju da tjelesna aktivnost ima važan utjecaj na zdravlje, poput bolje regulacije šećerne bolesti, smanjenja nastanka komplikacija šećerne bolesti, smanjenja krvnog tlaka, tjelesne težine, lošeg kolesterola (LDL), povećanje dobrog kolesterola (HDL), povećanja kardiorespiratornog kapaciteta, smanjenja smrtnosti te povećanja kvalitete života. ${ }^{7}$ Osim toga, uz tjelovježbu, odnosno terapijsku vježbu, potrebno je regulirati i prehranu. Osim što tjelesna aktivnost snižava glukozu u krvi i povećava osjetljivost na inzulin, pozitivno djeluje i na psihološki status. Nadalje, mišići tijekom aktivnosti troše više glukoze te zbog toga dolazi do smanjenja glukoze u krvi. Preporuke za tjelesnu aktivnost i mjere opreza određuju se prema zdravstvenom statusu i individualnim karakteristikama. Osobe s dijabetesom mogu provoditi sve oblike tjelovježbe, ali uz oprez. Tjelesna aktivnost utječe na regulaciju glukoze u krvi kod dijabetesa tipa 2, utječe na smanjenje tjelesne mase koja je ključna kod ovog tipa dijabetesa (posebice je opasna visceralna debljina), povećava osjetljivost na inzulin, smanjuje kardiovaskularne rizike te općenito popravlja opće stanje organizma. Redovita tjelesna aktivnost također je važna u prevenciji dijabetesa $i$ može odgoditi pojavu bolesti.

Redovita tjelovježba vrlo je važna i za oboljele od dijabetesa tipa 1 jer utječe na inzulinsku osjetljivost i kardiovaskularni status te poboljšava kondiciju i pojačava mišićnu snagu. Osobe s dijabetesom tipa 1 moraju dobro poznavati svoju bolest i znati kako je kontrolirati. Naime, kod dijabetesa tipa 1 postoji opasnost od hipoglikemije zbog povećane osjetljivost mišića na inzulin pa stoga bolesnici moraju biti dobro educirani kako bi prepoznali njezine znakove.

Prije provođenja terapijske vježbe potrebno je napraviti fizioterapijsku procjenu koja se sastoji od uzimanja anamneze, cjelovite vizualne procjene $\mathrm{i}$ testiranja, a zatim se dogovara terapijski proces. ${ }^{8}$ Upoznavanje statusa pacijenta kroz razgovor s pacijentom o svim simptomima koje ima vrlo je važno, kao i fizioterapeutova vizualna potvrda te procjena dodirivanjem ugroženog dijela tijela. ${ }^{8}$ Također je potrebno znati o operativnim zahvatima koje je pacijent imao ${ }^{8}$ te bolesti koje je pacijent prebolio ili još uvijek od njih boluje, a relevantne su za provođenje terapijske vježbe. Kod fizioterapijske procjene promatramo osobu u stojećem položaju, gdje sprijeda zamjećujemo međusobne odnose gležnjeva, koljena, zdjeličnog obruča, pozicija ključnih kosti i ramena te poziciju glave. ${ }^{8}$ Nadalje, bočno promatramo fiziološke krivine, straga gledamo postoji li rotacija tijela te postoje li iskrivljenja kralježnice u lijevo ili desno. ${ }^{8} \mathrm{U}$ ležećem položaju provodimo niz testova kojima procjenjujemo pozicije, međusobne odnose, odsutnost pokreta ili blokade mekih tkiva (mišića, fascija, ligamenata). ${ }^{8}$ Prije provođenja tjelesne aktivnosti potrebno je izmjeriti šećer u krvi kako bismo znali koji je oblik tjelovježbe i kojim intenzitetom potrebno provoditi. Zbog oštećenja periferne cirkulacije na različitim tjelesnim sustavima javljaju se smetnje vida, sluha i ravnoteže te promjene na srcu i krvnim žilama. ${ }^{8}$ Suradnjom oboljelog i fizioterapeuta može se postići zajednički cilj u vidu smanjenja ili ublažavanja navedenih simptoma, primjenom raznih fizioterapijskih metoda. ${ }^{8}$ Prilikom provođenja terapijske vježbe potrebno je sagledati pacijentove sposobnosti, ograničenja i ciljeve te se na temelju dobivenih parametara izrađuje plan aktivnosti. ${ }^{8}$

\subsection{Vrste tjelesne aktivnosti}

Aerobna vježba podrazumijeva kontinuirane i ponavljajuće pokrete velikih mišićnih skupina te obuhvaća aktivnosti kao što su plivanje, trčanje ili vožnja bicikla. ${ }^{5}$ Navedene aktivnosti koriste aerobne izvore energije u stanici. Aerobni izvori energije prevladavaju kada je u tkivima prisutno dovoljno kisika koji može zadovoljiti potrebe za proizvodnjom energije u stanicama pa su tako aerobne aktivnosti dugotrajnije i nižeg intenziteta. Vježbe snage, pri kojima stanice koriste anaerobne izvore energije, uključuju vježbe s elastičnom trakom, utezima, vlastitom težinom te strojevima za tjelovježbu. ${ }^{9}$ Vježbe fleksibilnosti povećavaju pokretljivost zglobova. ${ }^{9}$ Vježbe balansa, odnosno ravnoteže preveniraju mogućnost pada i pospješuju hod. ${ }^{10}$ Poneke aktivnosti mogu obuhvaćati i više vrsti tjelovježbe; primjerice tai chi i joga obuhvaćaju vježbe snage, balansa i fleksibilnosti. ${ }^{9}$

Aerobna aktivnost povećava inzulinsku osjetljivost, pospješuje funkciju pluća, povećava HDL, smanjuje kole- 
sterol, povećava volumen krvi, povećava mišićni tonus, a popravljaju se i enzimske funkcije u mišićima. ${ }^{9}$ Kod dijabetesa tipa 1 aerobna tjelovježba povećava cjelokupno zdravlje kardiovaskularnog sustava, smanjuje inzulinsku rezistenciju te popravlja lipidni status. Kod dijabetesa tipa 2 redovita tjelovježba smanjuje HbA1c, razinu triglicerida, krvni tlak te smanjuje inzulinsku rezistenciju. ${ }^{9}$ Nadalje, trening visokog intenziteta, takozvani HIT (engl. high intensity training), potiče osjetljivost na inzulin, regulira glikemiju kod dijabetesa tipa 2 te dolazi i do povećanog primitka kisika. ${ }^{9}$ Vježbe snage bilo kojeg intenziteta preporučuju se oboljelima od dijabetesa jer poboljšavaju snagu i ravnotežu te pozitivno utječu na glikemijski status. ${ }^{8}$ Nadalje, vrlo je važno napomenuti da osobe koje započinju s primjenom vježbi snage moraju biti pod nadzorom trenera ili druge stručne osobe te moraju biti svjesne da tijekom vježbi dolazi do pada vrijednosti glukoze zbog povećane potrošnje i povećanja inzulinske osjetljivosti. ${ }^{12}$ Vježbe balansa i fleksibilnosti važnije su za starije osobe $s$ dijabetesom. ${ }^{9}$ Vježbe fleksibilnosti pozitivno utječu na zglobove, odnosno povećavaju opseg pokreta i samim time omogućavaju bolju pokretljivost tijela, iako direktno ne utječu na snižavanje šećera u krvi. Joga i tai chi mogu se također provoditi na temelju osobnih preferencija pojedinca te se tim aktivnostima može povećati fleksibilnost, balans i snaga. ${ }^{9}$

\subsection{Utjecaj tjelovježbe na regulaciju dijabetesa tipa 1}

Kod dijabetesa tipa 1 razina glukoze za vrijeme vježbanja ovisi o nekoliko čimbenika: intenzitetu i trajanju tjelovježbe, vrsti i dozi uzetog inzulina, mjestu primjene inzulina, regulaciji dijabetesa te uzimanju obroka. ${ }^{1}$

Trajanje vježbi i intenzitet vrlo su važni; duže i intenzivnije vježbanje može rezultirati hipoglikemijom pa stoga osobe oboljele od dijabetesa tipa 1 moraju biti na oprezu tijekom provođenja tjelovježbe, ${ }^{1}$ odnosno potrebno je dobro regulirati glikemiju kako do hipoglikemije ne bi došlo. Na primjer, trčanje maratona ili skijaško trčanje može dovesti do hipoglikemije koja može nastupiti nakon nekoliko sati ili sljedeći dan. Hipoglikemija se može spriječiti ako se prije aktivnosti konzumira obrok bogat ugljikohidratima. ${ }^{1}$ Važno je naglasiti da i trenirani i netrenirani bolesnici prije početka tjelovježbe moraju konzumirati ugljikohidrate te smanjiti dozu inzulina kako bi izbjegli mogućnost pojave hipoglikemije. ${ }^{11}$ Različite vrste vježbi različito utječu na razinu glukoze. Aerobne aktivnosti u pravilu smanjuju glikemiju, anaerobne mogu povećati glikemiju, a mješovite aktivnosti održavaju glikemiju stabilnom. Status glukoze ovisi i o brojnim drugim faktorima kao što su: trajanje i intenzitet aktivnosti, početna razina glukoze, koncentracija inzulina, glukagona i drugih hormona, kondicija te prehrambene navike pojedinca. ${ }^{11}$

\subsection{Utjecaj tjelesne aktivnosti na regulaciju dijabetesa tipa 2}

Kod oboljelih od dijabetesa tipa 2 preporučuje se provoditi tjelovježbu ili terapijske vježbe (aerobne vježbe i vježbe snage) svaki dan ili barem svaki drugi dan kako bi se održavala odgovarajuća razina glikemije. Za održavanje odgovarajuće glikemije kombinirane aerobne vježbe i vježbe snage daju nabolje rezultate. ${ }^{9}$ Nadalje, osobe oboljele od dijabetesa tipa 2 imaju obično tijekom većeg dijela dana povišene razine glukoze u krvi, iako uzimaju peroralne antidijabetike ili inzulin. ${ }^{13}$ Stoga je tjelesna aktivnost vrlo važna u liječenju dijabetesa tip 2. Glukoza u krvi smanjuje se djelovanjem inzulina i mehanizmom koji je neovisan o inzulinu, odnosno mišićnom aktivnošću. Mišićna kontrakcija može povećati transport glukoze u mišiće, jer dolazi do premještanja proteinskog nosača za glukozu tipa GLUT-4 iz unutrašnjosti stanice na staničnu membranu. Tjelesna aktivnost povećava propusnost membrane za glukozu tako što utječe na povećanje ugradnje glukoze tipa GLUT-4 u staničnu membranu..$^{13}$

\subsection{Tjelovježba i komplikacije dijabetesa}

Ako su prisutne komplikacije dijabetesa, kao što su bolesti bubrega, retinopatija, neuropatija, kardiovaskularne bolesti ili promjene na zglobovima, potreban je oprez i ograničenje tjelovježbe ili prilagođene terapijske vježbe. ${ }^{9}$

Kod nefropatije vježbe snage i aerobne vježbe unaprjeđuju tjelesnu funkciju i kvalitetu života oboljelih od bubrežne bolesti. Sve su aktivnosti dozvoljene, ali moraju se provoditi niskim intenzitetom jer je funkcija mišića oslabljena. ${ }^{9}$ Kod mikroalbuminurije sve su aktivnosti dozvoljene, iako je potrebno izbjegavati tjelovježbu visokog intenziteta dan prije testiranja urina. ${ }^{9}$

Kod neprogresivne retinopatije dozvoljena je samo lagana tjelovježba i primjerena terapijska vježba. Kod osoba koje imaju retinopatiju potrebno je izbjegavati sportove koji mogu naglo povećati krvni tlak, kao što je primjerice dizanje utega. ${ }^{1}$ Nestabilna progresivna retinopatija može dovesti do staklastog krvarenja i odvajanje retine. Kod krvarenja u staklovinu oka tjelovježba je 
zabranjena. ${ }^{9}$ Kardiovaskularne su bolesti koje se javljaju kao komplikacije dijabetesa infarkt miokarda, hipertenzija, koronarna bolest, srčani udar, zatajenje srca, bolest perifernih arterija i stabilna angina. ${ }^{9}$ Kod koronarne bolesti arterija sve su aktivnosti dozvoljene uz nadzor, ali važno je naglasiti da vježbe snage i aerobne vježbe većeg intenziteta mogu poboljšati propusnost arterija. ${ }^{9}$ Naime, aerobne vježbe i vježbe snage zajedno smanjuju krvni tlak kod hipertenzije, stoga tjelovježbu treba poticati. Potrebno je izbjegavati Valsalvin manevar kod treninga snage i konzumirati dovoljno tekućine. ${ }^{9}$ Kod simptoma infarkta miokarda potrebno je odmah obustaviti tjelovježbu. Dominantni su simptomi bol u prsima i kratak dah. Nakon infarkta tjelovježba (vježbe snage i aerobne vježbe) je dozvoljena pod nadzorom. Intenzitet same vježbe mora se postupno pojačavati od niskog prema umjerenom. ${ }^{9}$

Oboljeli od dijabetesa mogu imati promjene na zglobovima koje mogu ograničiti pokret. Stoga su vježbe istezanja vrlo važne za povećanje opsega pokreta te se mogu izvoditi prije ili nakon tjelovježbe. Preporuka je jačanje mišića između zahvaćenih zglobova vježbama snage. ${ }^{9}$ Kod artritisa treba poticati tjelovježbu umjerenog intenziteta jer umjerena aktivnost smanjuje bol i smanjuje simptome bolesti. Dozvoljena je niska do umjerena aktivnost, a preporučuju se vježbe bez velikih opterećenja kako se stanje zgloba ne bi pogoršalo. Također, ne preporučuju se kontaktni sportovi. ${ }^{9}$

\subsection{Preporuke za provođenje tjelovježbe ili terapijskih vježbi kod oboljelih od dijabetesa}

Tjelovježba ili terapijske vježbe moraju biti koncipirane tako da se prvo provode vježbe zagrijavanja u trajanju od 5 do 10 minuta kako bi se mišići pripremili za daljnji napor. ${ }^{1}$ Isto tako, važno je i istezanje prije aktivnosti, ali bez zadržavanja daha zbog Valsalvina učinka. Nakon tjelovježbe provode se vježbe opuštanja kako bi se izbjegle komplikacije povezane s mišićno-koštanim i kardiovaskularnim sustavom. ${ }^{1}$

Većina autora navodi da je prije započinjanja programa tjelovježbe potrebno obaviti liječnički pregled, posebice ako su prisutne dijabetičke komplikacije. Važno je da je dijabetes pod kontrolom i da je bolest dobro regulirana te da nema zapreka za bavljenje tjelovježbom. Dijabetičari mogu provoditi različite oblike tjelovježbe prema vlastitom interesu i sposobnostima. ${ }^{1}$ Intenzitet i opseg tjelovježbe potrebno je postupno povećavati te prema promjenama u metabolizmu glukoze prilagođavati ko- ličinu i vrstu obroka, kao i dozu inzulina. ${ }^{1}$ Aerobna aktivnost preporučuje se za dijabetes tip 1 i 2 . Aktivnosti koje se provode mogu biti npr. šetnja, vožnja bicikla, plivanje ili HIT trening. Aerobna aktivnost trebala bi se provoditi barem 10 minuta dnevno s ciljem da se postigne provođenje aktivnosti na 30 minuta dnevno i više. Osobe oboljele od dijabetesa tipa 2 trebale bi provoditi tjelesnu aktivnost većinu dana u tjednu. ${ }^{9}$ Oboljelima se preporučuje umjerena do snažna aktivnost u trajanju od 150 minuta tjedno, uz postupno pojačavanje intenziteta, trajanja i učestalosti vježbanja. Kombiniranje HIT treninga sa stalnom tjelovježbom također je poželjno. ${ }^{8}$ Hodanje se u mnogim istraživanjima pokazalo kao poželjna aktivnost zbog svoje dostupnosti i jednostavnosti. Umjereno do brzo hodanje ima utjecaj i na prevenciju i smanjenje rizika nastanka dijabetesa tipa $2 .^{14}$

Vježbe snage podrazumijevaju vježbe na spravama, vježbe s elastičnim trakama, vježbe s utezima te vježbe $s$ težinom vlastitog tijela. Vježbe se mogu provoditi umjerenim intenzitetom uz 15 ponavljanja ili jakim intenzitetom uz šest do osam ponavljanja. Preporučuje se osam do deset vježbi u jednom do tri seta uz 10-15 ponavljanja, i to dva do tri puta tjedno. ${ }^{9}$

Vježbe za fleksibilnost i balans mogu biti statičke i dinamičke, a uključuju i druge vrste vježbi, kao što je primjerice joga. Vježbe balansa podrazumijevaju vježbe kao što su stajanje na jednoj nozi, tai chi, vježbe koje se izvode uz pomoć opreme za vježbanje, a pospješuju balans te vježbe za donji dio tijela i jačanja mišića trupa (engl. core). ${ }^{9}$ Intenzitet vježbi fleksibilnosti odnosno istezanja preporučuje se do točke u kojoj osoba počinje osjećati zategnutost ili laganu neugodu. Vježbe fleksibilnosti potrebno je provoditi statički ili dinamički 10 do 30 sekundi uz dva do četiri ponavljanja za svaku vježbu. ${ }^{9}$

\section{Zaključak}

Incidencija i prevalencija šećerne bolesti u porastu je, što se povezuje s lošim prehrambenim navikama, ubrzanim načinom života, nedovoljnim kretanjem, stresom i manjkom brige o zdravlju. Edukacija oboljelih od presudne je važnosti za kontrolu bolesti i svaki oboljeli mora poznavati bolest i način kako se nositi s njome. Primjerice, tjelesna aktivnost u obliku tjelovježbe ili terapijskih vježbi smatra se vrlo važnom u prevenciji i reg- 
ulaciji bolesti te uz pravilnu prehranu i primjenu inzulina omogućava oboljelima da bolest uspješnije drže pod kontrolom. Redovita tjelesna aktivnost održava odgovarajuću razinu glikemije, što je cilj kod svakog dijabetičkog bolesnika. Preporučene su aktivnosti aerobne vježbe, vježbe snage te vježbe fleksibilnosti i balansa. Oboljeli od dijabetesa mogu provoditi sve aktivnosti uz određeni oprez $u$ intenzitetu, trajanju i učestalosti provođenja aktivnosti, a u obzir treba uzeti i dijabetičke komplikacije koje predstavljaju određena ograničenja u provedbi aktivnosti. Isto tako, potrebno je kontrolirati glukozu u krvi prije, za vrijeme i na kraju aktivnosti, kako bi se na temelju tih parametara mogla planirati odgovarajuća tjelesna aktivnost. Tjelovježba mora biti planirana i dobro strukturirana za svakog oboljelog kako bi se izbjegle moguće komplikacije kao što su hipoglikemija i hiperglikemija. Svaki oboljeli odabire aktivnost koja mu odgovara po dobi, sposobnostima i interesima te samoj bolesti, odnosno njezinim komplikacijama, ako su prisutne.

\section{Referencije}

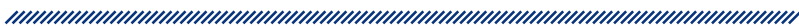

1. Mišgoj-Duraković M i sur. Tjelesno vježbanje i zdravlje, Zagreb: Grafos; 1999.

2. Rogić M, Crnek S, Vuletić LJ. Šećerna bolest, Zagreb: Medicinski fakultet sveučilišta Zagrebu; 1989.

3. International Diabetes Federation. IDF Diabetes Atlas [internet]. Brussels: International Diabetes Federation; 2015. Dostupno na: https://www.idf.org/e-library/epidemiology-research/diabetes-atlas.html (pristupljeno 8.10.2017.).

4. Jajić I, Jajić Z, i suradnici Fizikalna i rehabilitacijska medicina: Osnove i liječenje, Medicinska naklada, Zagreb, 2008.

5. World Health Organization [internet]. Physical activity 2017; Dostupno na: /http://www.who.int/topics/physical_activity/en/ (pristupljeno 1.10.2017.).

6. Poljičanin T, Metelko Ž. Epidemiologija šećerne bolesti u Hrvatskoj i svijetu, Sveučilišna klinika za dijabetes, endokrinologiju i bolesti metabolizma Vuk Vrhovac [internet] Zagreb: Medix 2009. Dostupno na: https://hrcak. srce.hr/file/102524 (pristupljeno 20.11.2017.).

7. Martinac K. Sport i dijabetes, KB Merkur, Sveučilišna klinika za dijabetes, endokrinologiju i bolesti metabolizma Vuk Vrhovac, Zagreb: Slatki život, Dijabetes; 2018.

8. Brozd J. Uloga fizioterapeuta u životu oboljelog od dijabetesa, Zagreb: Slatki život, Dijabetes; 2018.

9. Colberg SR, Sigal RJ, Yardley JE, Riddell MC, Dunstan DW, Dempsey PC, Horton ES, Castorino K, Tate DF. Activity/Exercise and Diabetes: A Position Statment of the American Diabetes Association, Diabetes Care [internet]; 2016. Dostupno na: http://care. diabetesjournals.org/content/39/11/2065. full-text.pdf (pristupljeno 6.10.2017.).

10. Udruga za skrb djece s posebnim zdravstvenim potrebama 3L. ADA, Smjernice za tjelovježbu [internet]. San Diego; Udruga za skrb djece s posebnim zdravstvenim potrebama; 2017. Dostupno na: http://www.3ludruga.hr/ada2017-smjernice-za-tjelovjezbu/ (pristupljeno 26.11.2017.).

11. Riddel MC, Gallen IW, Smart CE, Taplin CE, Adolfsson P, Lumb AN, Kowalski A, Rabasa-Lhoret R, McCrimmon RJ, Hume C, Annan F, Fournier PA, Graham C, Bode B, Galassetti P, Jones TW, San Milan I, Heise T, Peters AL, Petz A, Laffel LM. Exercise management in type diabetes: a consensus statement, The Lancet, Diabetes\& Endocrinology [internet]; 2017. Dostupno na: http://www.thelancet. com/journals/landia/article/PIIS2213-8587(17)30014-1/ fulltext (pristupljeno 2.10.2017.).

12. Baretić M. Fizička aktivnost i šećerna bolest, Zagreb: Klinički bolnički centar Zagreb, Acta Med Croatica [internet]; 2017. Dostupno na: https://hrcak.srce.hr/file/272618 (pristupljeno 26.10.2017.).

13. Heimer S. Tjelesna aktivnost i zdravlje. Znanstvenostručna konferencija; 23. studenoga 2013.; Zagreb

14. Caspersen CJ, Fulton JE. Epidemiology of walking and type 2 diabetes. Medicine and Science in Sports and Exercise [internet]; 2008. Dostupno na: https://www.ncbi.nlm. nih.gov/pubmed/18562969 (pristupljeno 25.10.2017.). 


\section{IMPORTANCE OF EXERCISE IN DIABETES}

\author{
1 Petra Šulevski \\ 1 Ivna Kocijan \\ 1 University of Applied Health Sciences, Zagreb
}

\section{Abstract}

There is an increasing number of people with diabetes, both in the world and in Croatia. Estimates speak of a total of 415 million people. The number of people with diabetes, especially those diagnosed with type 2 diabetes, indicates a disorderly way of life, poor eating habits, sedentary lifestyle and stress. The treatment of diabetes is carried out with proper nutrition, regular physical activity and medication therapy, all in order to regulate glycemia. Physical activity is an integral part of the diabetes treatment because it maintains an adequate glycemic level, improves lipid status and increases cell sensitivity to insulin. Furthermore, the need for insulin is reduced because the mechanism of muscle contraction increases glucose consumption.

All kinds of physical activity are allowed, sometimes with certain individual limitations, and most benefit is expected when exercise is performed regularly with moderate intensity but with particular caution, especially if complications of the disease are present.

Special attention should be paid to the risk of hypoglycaemia, as it reduces glucose levels during exercise. Before carrying out physical activity, it is necessary to check the level of glucose and adjust or postpone the activity in case of excessive or too low glucose levels.

Studies have shown that aerobic and anaerobic activities affect the regulation of glucose. First of all, flexibility exercises are recommended (though they do not have a direct impact on glucose reduction), as well as balance excercises that reduce the chance of falling. It is recommended to undertake 150 minutes a week of moderate to strong activity. For example, exercises can be performed with moderate intensity at 15 repetitions or high intensity with 6 to 8 repeats.

We can conclude that regular exercise is necessary to preserve the health and life quality of people affected with diabetes.

Keywords: type 1 diabetes, type 2 diabetes, exercise, glucose control 